\title{
EFFECT OF LONG-TERM POTASSIUM FERTILIZER LEVELS ON THE YIELD OF RAINFED CORN IN NORTHEAST CHINA
}

\author{
WANG, Y. - ZHANG, T. - LI, B. - FENG, G. - YAN, L. ${ }^{*}$-GAO, Q.* \\ Key Laboratory of Groundwater Resources and Environment, Ministry of Education, Jilin \\ University, Changchun 130021, China
}

College of Resource and Environment, Jilin Agricultural University, Changchun 130118, China

*Corresponding authors

e-mail/phone: yanlijau@163.com/+86-155-2686-6351; gaoqinglunwen@163.com/+86-131-

$3445-7702$

(Received $3^{\text {rd }}$ Apr 2019; accepted $12^{\text {th }}$ Dec 2019)

\begin{abstract}
The excessive application of potassium (K) fertilizer over the last 30 years has resulted in considerable resource waste and environmental risk. In order to economize and protect the environment, China launched a soil testing and fertilizer recommendation project from 2005 to 2015 . A total of 1370 on-farm experiments were conducted concerning maize fields in Jilin Province Northeast China, also called the golden maize (Zea mays L.) belt, over the past ten years to evaluate the effects of the implemented project and to provide farmers with an improved fertilizer recommendation system. The results showed that the average yield of maize with $\mathrm{K} 0$ treatment was $9000 \mathrm{~kg} \mathrm{ha}^{-1}$. Its maximum yield (Max.yield) and increased yield (IY k) after application of $\mathrm{K}$ fertilizer averaged at $10200 \mathrm{~kg} \mathrm{ha}^{-1}$ and $1100 \mathrm{~kg} \mathrm{ha}^{-1}$, respectively. Significant variability was evident in K0 yield and Max.yield over the years. Maize hybrids and different soil types had significant differences in IY yield. Meanwhile, IY k can either increase or decrease depending on $\mathrm{K} 0$ yield, which suggest that a suitable $\mathrm{K}$ fertilizer can improve the yield, whereas excessive fertilizing would have no obvious effect on the yield. In addition, the yield was found to be affected by environment, maize hybrids, soil types, and $\mathrm{K}$ fertilizer rate.
\end{abstract}

Keywords: increasing yield, soil fertility, hybrids, soil types, fertilizer use efficiency

\section{Introduction}

Alongside developing modern hybrids and improving agronomic management, fertilizer use is recognized in China as one of the key methods for increasing yield. Indeed, the effects of nitrogen $(\mathrm{N})$ and phosphorus $(\mathrm{P})$ fertilizers on corn production have been extensively studied; however, the effect of potassium $(\mathrm{K})$ fertilizer has not been given much attention. As one of the three major plant macronutrients, potassium has multiple functions in the activation of cellular enzymes; the synthesis of proteins, starch, cellulose, and vitamins; the development of resistance to abiotic and biotic stresses; the improvement of $\mathrm{N}$ and $\mathrm{P}$ fertilizer use efficiency; and the enhancement of productivity and quality of agricultural produce (Ogundijo et al., 2017; Chen et al., 2012a; Epstein and Bloom, 2005). Neglect of the importance of potassium coupled with high input of inorganic $\mathrm{N}$ and $\mathrm{P}$ fertilizers to meet the continually increasing demand for food has resulted in their low use efficiency, as well as $\mathrm{N}: \mathrm{P}: \mathrm{K}$ imbalance in plant and soil systems leading to severe eutrophication (Tian et al., 2017; Zhang et al., 2011). Potassium deficiency is a nationwide phenomenon, with approximately $43 \%$ of soils requiring additional potassium (Zoerb et al., 2013). However, excessive application of potassium fertilizer, which could persist in the soil for years after application, is also a documented occurrence (Xie, 2000; Tenkorang and Lowenberg-DeBoer, 2009). 
Therefore, determining the appropriate potassium input is crucial to the achievement of high yield and high efficiency.

China produced $155 \mathrm{Mt}$ of maize (Zea mays L.) in 2007 (National Bureau of Statistics of China, 2007; Wang et al., 2007), which made the country the second largest producer of maize worldwide (Zhang et al., 2011). In 2017, the yield of maize increased to $259 \mathrm{Mt}$ (National Bureau of Statistics of China, 2011). The increase of yield was apparent in Northeast China, particularly in Jilin Province, which increased from $18 \mathrm{Mt}$ in 2007 to 32.5 Mt in 2017 (National Bureau of Statistics of China, 2017). The recent long-term application of $\mathrm{K}$ fertilizer may be one of the reasons for this improvement.

Several studies have demonstrated that long-term potassium fertilizer application can maintain crop productivity and soil quality (Wang et al., 2007), and that K efficiency and partial balance condition can affect crop yield (Zhang et al., 2011). However, studies on the relationship between corn yield and the long-term application of potassium fertilizer in Northeast China are scarce. In 2005, China launched a nationwide soil testing and fertilizer recommendation project to mitigate excessive and unbalanced fertilizer application. Hereby, we just chose the data in Jilin Province as analysis sample due to large amount of data in whole project, the objective of this study was to examine the ten-year experiment of "soil testing and fertilizer recommendation" in Northeast China from 2005 to 2015 and to determine (1) the relationship between corn yield and potassium fertilizer in $\mathrm{K}$ deficient and $\mathrm{K}$ excessive conditions, and (2) whether the amount of recommended $\mathrm{K}$ rate (RKR) was optimized by the $\mathrm{K}$ fertilizer to satisfy the K requirement of corn.

\section{Materials and methods}

The study area was located in Jilin province in Northeast China with between $40^{\circ}$ and $47^{\circ} \mathrm{N}$ latitude and between $121^{\circ}$ and $131^{\circ} \mathrm{E}$ longitude in the east of Eurasian continent in the middle latitude, which is not only one of the three black soil regions in the world, but also one of three golden corn belts in the world. The climate in the study area is warm-temperate, sub-humid, continental monsoon with cold winters and hot summers. Annual precipitation ranges from $500 \mathrm{~mm}$ to $800 \mathrm{~mm}$, with 60 to $70 \%$ of the rainfall occurring in the summer. No irrigation was supplied during the corn-growing season. There are more than 30 counties in nine cities in Jilin province with $187400 \mathrm{~km}^{2}$. The soil types primarily included Haplic Luvisol, Albic Luvisol, Haplic Phaeozem, Cambisol, Haplic Kastanozem, Calcaric Arenosol, Haplic Chernozeme, and Luvic Phaeozem (http://en.wikipedia.org/wiki/FAO_soil_classification; Gong et al., 1999).

\section{Experimental design}

A total of 1370 on-farm experiments on corn production were chose from 2005 to 2015 in 55 counties of Jilin Province (Fig. 1). All experimental fields received four K treatments without replication: No K control (K0), RKR, 50\% RKR, and 150\% RKR. RKR was determined according to the recommendations of an agronomist based on the estimated soil fertility and the target yield (1.1 times the average yield for the past five years, which varied by field). RKR values in different farm fields were different because of diverse soil condition and environmental variables.

The experiments were conducted on a continuous corn system, and new experimental sites were selected every year. Generally, one-third of $\mathrm{N}$ and the total $\mathrm{K}$ and $\mathrm{P}$ fertilizers 
were applied at pre-sowing, and the remaining two-thirds of $\mathrm{N}$ fertilizer was applied as top-dressing at around the six-leaf stage.

The plot size was approximately $40 \mathrm{~m}^{2}(4 \mathrm{~m} \times 10 \mathrm{~m})$. Based on soil $\mathrm{N}$ and P levels, all plots received sufficient amounts of urea (185 kg to $\left.250 \mathrm{~kg} \mathrm{~N} \mathrm{ha}^{-1}\right)$ and triple superphosphate (60 kg to $120 \mathrm{~kg} \mathrm{P}_{2} \mathrm{O}_{5} \mathrm{ha}^{-1}$ ) at pre-sowing. No organic manure was applied. All experiments were managed according to the same practices of each individual producer except for implementing the treatments and obtaining crop and soil samples, which were conducted by the researchers. A total of 71 maize hybrids were used in the experimental sites, which belong to four typical variety series in Jilin province, such as Zhengdan, Jidan, Xianyu, and Nongda, and these were individually selected by the farmers. Moreover, all hybrids had high yield potential. The corn was planted in the beginning of May and was harvested by the end of September. Weeds were controlled with herbicide after seedling, and no obvious water or pest stress was observed during the corn-growing seasons (the data in disaster such as flood, pest disaster, extreme drought in some trial sites and incomplete data have been eliminated). The plant population was about 55000 with $60 \mathrm{~cm}$ row spacing, which is typical in Jilin Province.

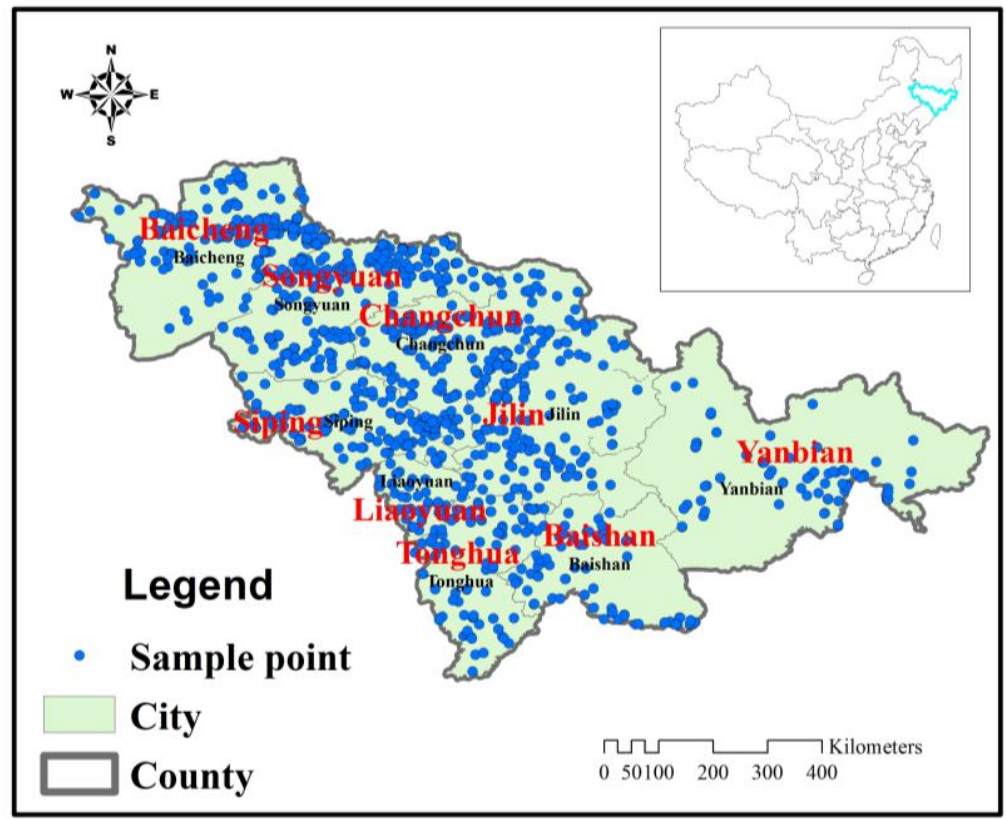

Figure 1. Sample point information map

\section{Sampling and laboratory procedures}

At least three samples of $20 \mathrm{~cm}$ soil layer were obtained from each field for all of the plots. The samples were air-dried, sieved, and used to measure the exchanged-K (Van Reeuwijk, 1992). For each experiment, gain yield at maturity was assessed by hand on a $2.5 \mathrm{~m} \times 8 \mathrm{~m}$ section of each plot, and the value was adjusted to $14 \%$ moisture.

\section{Data analysis}

All experimental data were analyzed with correlation analysis method by using software SAS. Single factor analysis was employed to compare the mean yields of K 
treatments based on the least significant difference (LSD) at a 0.05 level of probability. Given the data complication, data on four common soil types (Albic soils, Chernozem, Aeolian sand, and Phaeozem) in Northeast China and four typical hybrids (Zhengdan, Jidan, Xianyu, and Nongda) in farmer fields across all treatments in the 1370 fields were selected and analyzed. The product of the dimension model and the years degrees of freedom $(\mathrm{df}=10)$, hybrids $(\mathrm{df}=3)$, and soil type $(\mathrm{df}=3)$ was used to assess the overall variability of the increased yield (IY k), the yield with N0 treatment, and the maximum yield (Max.yield).

Maximum grain yield was defined as the highest mean yield of all $\mathrm{K}$ treatments for each field. Increased yield for applied K fertilizer (IY k) was defined as the difference between Max.yield and the yield of the K0 treatment for each experiment. The agronomic $\mathrm{K}$ efficiency (AEK) and $\mathrm{K}$ partial factor productivity (PFPK) were calculated based on Equations 1 and 2 (Ladha et al., 2005). AEK is the yield increase per unit of $\mathrm{K}$ applied, and PFPK is the most significant index for farmers because it integrates the usage efficiency of both indigenous and applied $\mathrm{K}$ resources.

$$
\begin{gathered}
\mathrm{AEK}=(\mathrm{YK}-\mathrm{Y} 0) / \mathrm{K} \\
\mathrm{PFPK}=\mathrm{YK} / \mathrm{K}
\end{gathered}
$$

where $\mathrm{YK}$ and $\mathrm{Y} 0$ represent the grain yield in $\mathrm{K}$ application plots and $\mathrm{K} 0$ plots, respectively, and $\mathrm{K}$ is $\mathrm{K}$ from the applied fertilizer.

\section{Results}

\section{Yield, increasing yield, AEK and PFPK with different $K$ treatments}

In this study, soil organic matter, $\mathrm{TN}, \mathrm{TP}$, and $\mathrm{PH}$ in the top $20 \mathrm{~cm}$ soil profile averaged at $17.4 \pm 19.6 \mathrm{~g} \mathrm{~kg}^{-1}, 1.4 \pm 1.3 \mathrm{~g} \mathrm{~kg}^{-1}, 0.8 \pm 0.4 \mathrm{~g} \mathrm{~kg}^{-1}$, and $6.7 \pm 1.0$, respectively. These values are typical for rainfed corn production in Northeast China. The grain yield for the $\mathrm{K} 0$ treatment across all of the 1370 experiment fields averaged at 9.0 $\mathrm{Mg} \mathrm{ha}^{-1}$ and varied from 2.1 $\mathrm{Mg} \mathrm{ha}^{-1}$ to $17.9 \mathrm{Mg} \mathrm{ha}^{-1}$ (Table 1). Increasing yield rate resulting from $\mathrm{K}$ fertilizer input was $5.6 \%, 10.0 \%$, and $8.9 \%$ for $50 \% \mathrm{RKR}$, RKR and $150 \%$ RKR, respectively. So it can be seen that the $\mathrm{K}$ fertilizer is one of important factors to increase yield. Reasonable $\mathrm{K}$ fertilizer rate can reach the best effect of increasing yield comparing to less or excessive $\mathrm{K}$ fertilizer application. The RKR across 1370 experiment fields was $72 \pm 7.5 \mathrm{~K}_{2} \mathrm{O} \mathrm{kg} \mathrm{ha}{ }^{-1}$ and varied from $19.5 \mathrm{~K}_{2} \mathrm{O} \mathrm{kg} \mathrm{ha}{ }^{-1}$ to $180 \mathrm{~K}_{2} \mathrm{O} \mathrm{kg} \mathrm{ha}{ }^{-1}$. The grain yield of RKR averaged at $9.9 \mathrm{Mg} \mathrm{ha}^{-1}$ and varied from 2.1 to $17.0 \mathrm{Mg} \mathrm{ha}^{-1}$. AEK and PFPK for RKR averaged at 12.2 and $138.9 \mathrm{~kg} \mathrm{~kg}^{-1}$, respectively (Table 2). Compared with RKR, the addition of more K beyond RKR $(+50 \%)$ did not increase yields, but reduced AEK and PFPK. Treatments below RNR (-50\%) resulted in a $0.4 \mathrm{Mg} \mathrm{ha}^{-1}$ yield loss. Therefore, RKR is a reasonable range to attain maximum grain yield.

\section{Effect of years, hybrids and soil types on $K$ fertilizer and yield}

Year factor significantly affected the variation in Max.yield and K0 yield resulting from environmental factors such as rainfall, temperature, and insect pests (Table 1; $\mathrm{P}=0.01$ ). Max.yield among different years varied from $8.9 \mathrm{Mg} \mathrm{ha}^{-1}$ to $10.6 \mathrm{Mg} \mathrm{ha}^{-1}$. The mean Max.yield in 2008 was $10.4 \mathrm{Mg} \mathrm{ha}^{-1}$, which was caused by suitable rainfall 
and sunlight. The yield decreased in 2007 and 2009 because of drought. In addition, the yield decreased in 2010 because of the flood in certain parts of Jilin Province.

Table 1. Mean grain yield with different $K$ treatments, maximum yield (Max.yield), and increased yield to $K$ fertilizer (IYK), optimum $K$ fertilizer rate (OKR) with different sites, and their variation among 1370 experiment fields

\begin{tabular}{c|c|c|c|c}
\hline K treatment & Mean & $\mathbf{2 5 \%} \mathbf{Q}+$ & Median & $\mathbf{7 5 \%} \mathbf{Q}+$ \\
\hline Grain yield (t/ha) & & & & \\
\hline Yield at N0 & $9.0 \pm 1.8$ & 7.9 & 9.1 & 10.1 \\
Yield at 50\%RKR & $9.5 \pm 1.8$ & 8.5 & 9.5 & 10.6 \\
Yield at RKR & $9.9 \pm 1.8$ & 8.8 & 10 & 11.2 \\
Yield at 150\%RKR & $9.8 \pm 1.8$ & 8.7 & 9.9 & 11 \\
Max.yield & $10.2 \pm 1.8$ & 9.1 & 10.3 & 11.4 \\
IYK & $1.1 \pm 0.7$ & 0.7 & 1.1 & 1.6 \\
\hline Source of variation for yield at K0 treatment, Max.yield, IYK and OKR & IYk & OKR \\
\hline Source & K0 yield & Max.yield & $*$ & $*$ \\
Hybrids (3) & $* *$ & $* *$ & $* *$ & \\
Soil type (3) & $* *$ & $* *$ & ns & $*$ \\
Year (10) & $* *$ & $* *$ & & $*$ \\
\hline
\end{tabular}

Q: quartile; ns: nonsignificant at 0.05 probability levels. ${ }^{*} \mathrm{p}=0.05 ;{ }^{* *} \mathrm{p}=0.01$

Table 2. Mean agronomic K efficiency (AEK) and partial factor productivity (PFPK) and its variation with different $K$ treatments among 1370 experimental fields

\begin{tabular}{c|c|c|c|c|c}
\hline Item & K treatment & Mean & $\mathbf{2 5 \%} \mathbf{Q}$ & Median & $\mathbf{7 5 \%} \mathbf{Q}$ \\
\hline \multirow{3}{*}{$\mathrm{AE}_{\mathrm{K}}\left(\mathrm{kg} \mathrm{kg}^{-1}\right)$} & $50 \% \mathrm{RKR}$ & 12.7 & 1.2 & 11.5 & 23.7 \\
& $\mathrm{RKR}$ & 12.2 & 4.4 & 11.8 & 19.4 \\
& $150 \% \mathrm{RKR}$ & 7.1 & 1.9 & 7.2 & 11.6 \\
\hline \multirow{3}{*}{$\mathrm{PFP}_{\mathrm{k}}\left(\mathrm{kg} \mathrm{kg}^{-1}\right)$} & $50 \% \mathrm{RKR}$ & 266 & 232.1 & 267.6 & 300 \\
& RKR & 138.9 & 120.6 & 140.7 & 156.6 \\
& $150 \% \mathrm{RKR}$ & 91.5 & 80.2 & 92.8 & 102.5 \\
\hline
\end{tabular}

Q: quantile

Moreover, the different hybrids had extremely significant differences in Max.yield, K0 yield, and IY. Among the four typical maize (Zea mays L.) hybrids in Jilin Province, the Zhengdan hybrid has the highest K0 yield, which displayed higher tolerant ability of poor soil. However, the Xianyu hybrid has the highest Max.yield and IY, which indicate stronger sensitivity to potassium nutrition. The AE of the hybrid can be reflected by the following order: Xianyu $>$ Jidan $>$ Nongda $>$ Zhengdan. The Xianyu hybrid exhibits high increased yield regardless of the environment. For example, in 2008 and 2007, the Xianyu hybrid had absolutely high IY, which exhibited better increasing potential (data did not show).

The yield from four typical soil types in Jilin Province had extremely significant differences in K0 treatment and Max.yield. The yield from Aeolian sand was the lowest, 
whereas that from Phaeozem soils was the highest (Fig. 2). No difference in IY was observed. Optimum fertilizer rate was calculated via linear-regression analysis using SAS software. Results showed that the optimum fertilizer rate in Albic soils and Chernozem soils was generally higher than that in Aeolian sands. In an ideal environment, optimum $\mathrm{K}$ fertilizer rate in Albic soils, Phaeozem, Chernozem, and Aeolian sand soils was $63.2,82.2,58$, and $51.6 \mathrm{~kg} / \mathrm{ha}$, respectively. The optimum yield calculated by SAS software was similar to the average yield, which indicated that RKR was a rational range.

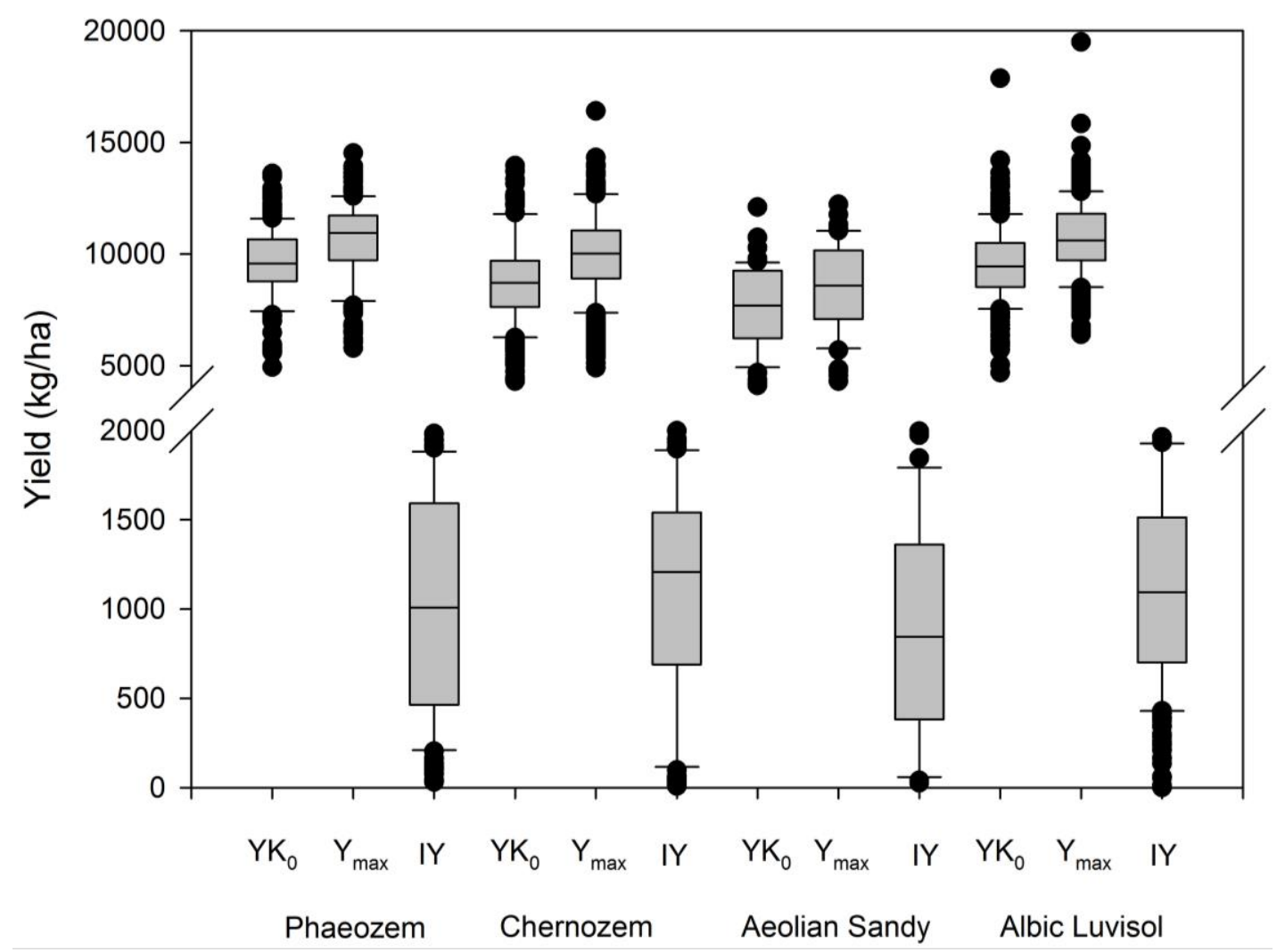

Figure 2. Averaged yield per hectare of 4 kinds of soil types in 2005-2010 in test fields. YKo means yield with $K 0$ treatment; $Y_{\max }$ means the maximum yield with $K$ treatment; IY means increasing yield. The upper and lower limits of each box represent $25 \%$ and $75 \%$ values, the horizontal solid lines inside the box indicate mean values, respectively

\section{The relationships among Max yield, increasing yield and KO yield}

A close relationship was found between Max.yield and yield of $\mathrm{K} 0$ treatment across all fields $(\mathrm{R} 2=0.87$; Fig. $3 A)$. The maximum grain yield increased as the yield of K0 treatment was increased. According to statistics, the rate of corn yield of RKR with respect to Max.yield is $52 \%$. The rate of corn yield of $150 \%$ RKR with respect to Max.yield is $42 \%$ in all fields. These results indicated that a sufficient amount of $\mathrm{K}$ fertilizer was applied, which resulted in high yield. However, compared with the RKR yield, the average yield of RKR was higher than the yield of $150 \%$ RKR, and agronomic efficiency of RKR was significantly higher than that of $150 \%$ RKR, which indicated that RKR was the suitable amount of fertilizer that must be applied in Northeast China. 
IY $\mathrm{k}$ has correlation with increasing yield of $\mathrm{K} 0$ treatment $(\mathrm{R} 2=0.1 ;$ Fig. $3 B)$. When the grain yield of $\mathrm{K} 0$ treatment is smaller than $8.0 \mathrm{Mg} \mathrm{ha}^{-1}$, IY k increases with the yield of $\mathrm{K} 0$ treatment. However, when the grain yield of $\mathrm{K} 0$ treatment is greater than $8.0 \mathrm{Mg}$ $\mathrm{ha}^{-1}$, IY $\mathrm{k}$ decreases with the yield of K0 treatment. This phenomenon shows that a suitable amount of $\mathrm{K}$ fertilizer can improve the grain yield in the soil with K deficiency. However, the increase in yield caused by the application of $\mathrm{K}$ fertilizer in soils of middle and high yield is not significant. Moreover, when the corn grain yield is extremely high (greater than $12.0 \mathrm{Mg} \mathrm{ha}^{-1}$ ), certain IY k were still higher (Fig. 3B). This finding partly indicated that the soils of certain plots were more fertile, which resulted in high yield, and the addition of $\mathrm{K}$ fertilizer input improved the soil fertility balance, which resulted in higher yield.
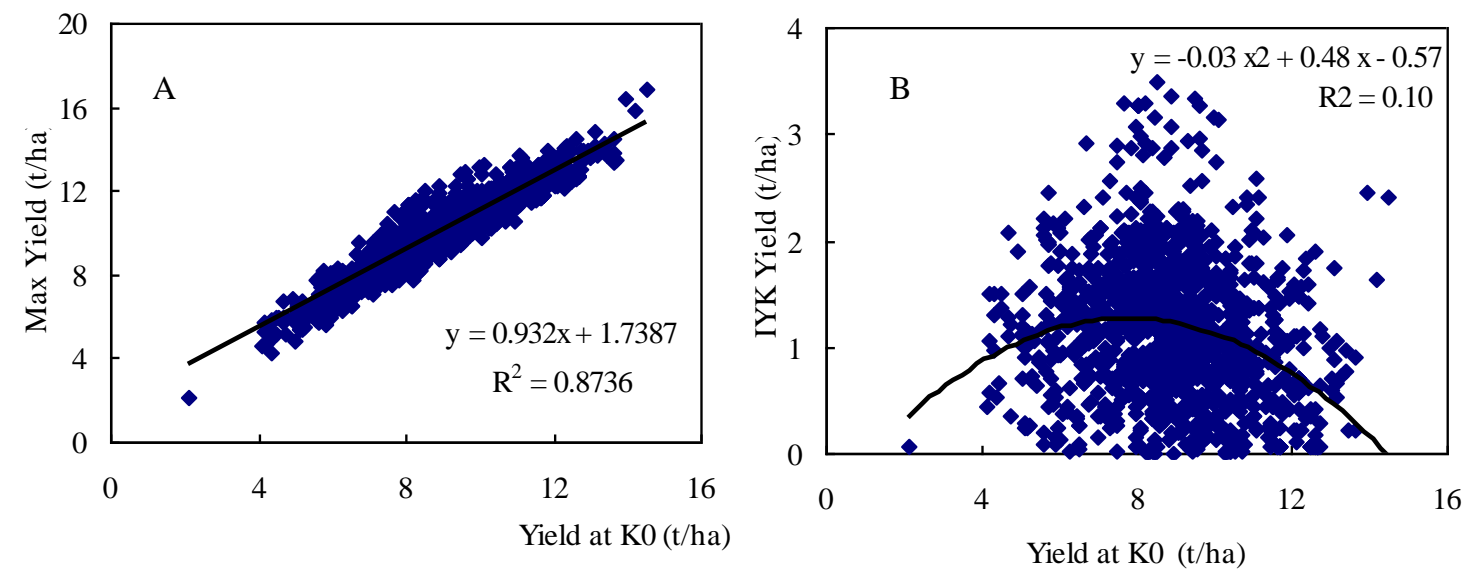

Figure 3. A Relationship between maximum yield (Max.yield) and grain yield at KO treatments across all 1370 fields. B Relationship between increase yield (IYk) to applied K fertilizer and grain yield at $\mathrm{KO}$ treatments across all 1370 fields

The percentage of IYk (Fig. 4) in maximum yield (IY k/Max.yield) decreased with increasing yield for $\mathrm{K} 0$ treatments, which suggested a conflict between improving usage efficiency and further increasing the yields (Gao et al., 2012).

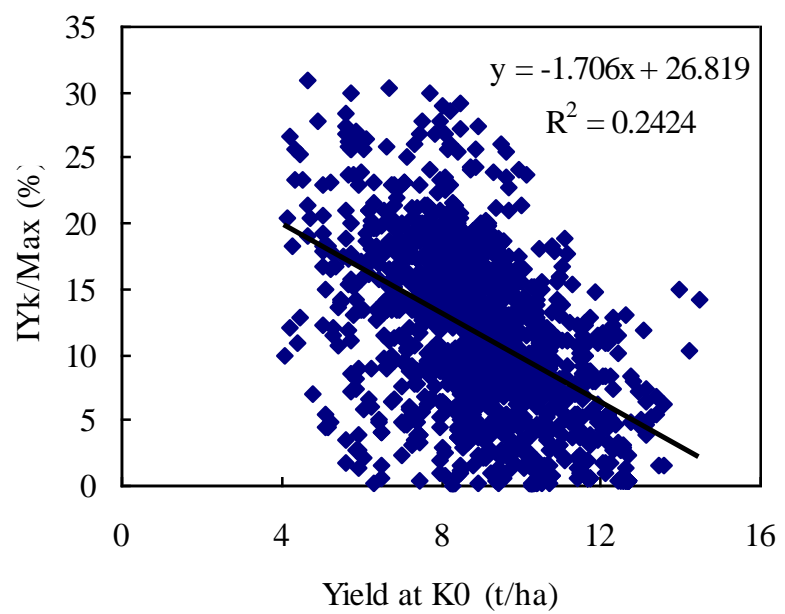

Figure 4. Relationship between the percentage of IYk in maximum yield (IY k/Max.yield) and grain yield at KO treatments across all 1370 fields 


\section{Discussion}

\section{Yield, increasing yield, AEK and PFPK}

Jilin Province in Northeast China is one of the three gold corn belts of the world. The province is the most significant maize-producing regions in China. As the population continues to grow, the amount of farmland has decreased in recent years. Therefore, adding yield per unit to increase maize production has been the focus of several studies in China. From the Chinese Revolution until today, maize yield per hectare has gone through several stages of rapid development with the emergence of maize hybrid varieties, fertilizer application, and management technology improvement (Ren et al., 2010). From 2005 to the 2011, the averaged yield per hectare is from $3.2 \mathrm{Mg} \mathrm{ha}^{-1}$ to $7.5 \mathrm{Mg} \mathrm{ha}{ }^{-1}$ because of the implementation of the soil testing and fertilizer recommendation project and the high-yield, high-efficiency management in Jilin Province (National Bureau of Statistics of China 2007; National Bureau of Statistics of China 2011), however the averaged $\mathrm{K}$ fertilization rate applied $\left(\mathrm{K}_{2} \mathrm{O}\right)$ is from $38.4 \mathrm{~kg}$ $\mathrm{ha}^{-1}$ to $42.1 \mathrm{~kg} \mathrm{ha}^{-1}$ due to decreased maize planting areas and increased potassium fertilizer emphasis, which is obviously lower than national maize averaged $82 \mathrm{~kg} \mathrm{ha}^{-1}(\mathrm{Li}$ et al., 2010). Averaged agronomical efficiency (AE) and partial factor productivity from applied fertilizer (PFP) of potassium in 2005-2015 in Jilin province is $17.3 \mathrm{~kg} \mathrm{~kg}^{-1}$ and $32.7 \mathrm{~kg} \mathrm{~kg}^{-1}$ which is obviously higher than average level in China ( $\mathrm{Li}$ et al., 2010). Compared with averaged yield per hectare in USA in $20059.3 \mathrm{Mg} \mathrm{ha}^{-1}$ and higher potassium use efficiency (Zhang et al., 2008), yield and fertilizer use efficiency in China were still lower mainly by three factors. First is farmer experience unconscious fertilization, farmers yet applied old notion of more input, then more output. Second is ignorant of mix application of organic and inorganic fertilizer, and of macro element and microelement fertilizer. Last is low level of mechanization.

\section{Effect of year, hybrids and soil types on $K$ fertilizer and yield}

According to above historical data, three factors affect the yield per unit of maize and potassium fertilizer rate. First is environmental condition such as temperature, sunlight, and rainfall. The suitable climate for maize growth consists of four distinct seasons, with abundant sunshine and rain at the same time (Li et al., 2001; Zheng and Dong, 2000), temperature and rainfall have significant correlation with maize yield (Peng et al., 2008; Drury and Tan, 1995). Moreover, moisture content in soil has obvious interaction with potassium fertilizer efficiency. Potassium in soil transport mainly by diffusion, and the water in soil was strongly affected diffusion condition. So it should be pay attention to apply potassium fertilizer in dry years, and decrease potassium fertilizer rate in higher rainfall years (Ortas, 2018; Shen et al., 2008).

Second, the development of hybrids affected yield and potassium fertilizer rate. China popularized breeding and corn hybridization during the 1960s, and yield per unit was increased by 2.5 times (Sun, 2010). The yields of different maize hybrids had obvious differences under the same conditions (Chen et al., 2012b). Dissimilar tolerance of such hybrids to drought or herbicide resulted in significant yield variability (Weber and Golebiowska, 2010; Vasal, 2000). The assessment of yield stability is a significant issue for maize cultivar evaluation and recommendation (Liu et al., 2011). Therefore, summarizing the requirements of selected maize hybrids is necessary in selecting highyield and stable-yield hybrids based on local climate conditions observed in previous years. And the characteristics of absorb potassium of different hybrids existed 
significant changed. The abilities of absorb potassium of different hybrids in soils and in fertilizer had difference, the divergence of potassium content in each stage can reach 0.9-1.6 times, so the hybrids of long-term and large quantities of absorbing potassium should apply base potassium fertilizer and top-dressing fertilizer (Wang et al., 2004).

Finally, soil types are crucial to improve yield and potassium use efficiency. Crop yield response was controlled by a complex interaction that varied annually with soil textural characteristics (Tolk et al., 1999). Soil textural affects water supply, ventilation, fertilizer supply, heat preservation and basic fertility of soil, also influenced soil physics, mechanics of machinery and a series of other characteristics. The yield per unit affected by climate and soils is close to real yield potential in the agreeable hybrids and management technology. Different soil types have different rational potassium rate and fertilization styles due to high spatial variability in soil $\mathrm{K}$ content, the forms and availability to plants of soil $\mathrm{K}$, i.e. potential $\mathrm{K}$-supplying capacity, were related to mineralogy in different soil types (Darunsontaya et al., 2012). In Jilin province available potassium contents of Phaeozem Soils and Chernozem Soils are higher and slowavailable potassium contents are relatively richer, the potential of potassium supply are huge; available potassium of Albic Soils is middle, the potential of potassium supply is limited, so it should be replenish proper potassium fertilizer; and available potassium and potential of potassium supply of Aeolian Sand Soils are lower, so it is necessary to increase potassium fertilizer and split application (Wang, 1998).

\section{The relationships among Max yield, increasing yield and KO yield}

Soil fertility determined Max yield, increasing yield and K0 yield of maize. The higher the soil fertility is, the higher K0 yield and Max yield are and the lower the potential of increasing yield is. Increasing yield has significant negative correlation with the available potassium content of soil (Wang et al., 2004). So identifying and quantifying soil fertility variation and subsequently determining the optimal fertilization levels associated with different management styles are necessary to implement nutrient management (Tabu et al., 2006). Rational fertilization improved fertilizer use efficiency, protected the environment, and maintained soil fertility for creating suitable soils. Therefore, modeling and calculating the optimal fertilization in different soils and different climate conditions based on experimental data analysis from previous years can guide farmers in the process of scientific fertilization.

\section{Conclusion}

The challenge of meeting food demand with less pollution on the environment in China in the next 50 years can be overcome by increasing usage efficiency simultaneously (Gao et al., 2012). The effect of "soil testing and fertilizer recommendation" project in China from 2005 to 2015 was remarkable. The results from Jilin province with 1370 field trials showed that the average yield of maize with K0 treatment was $9000 \mathrm{~kg} \mathrm{ha}^{-1}$. Its maximum yield (Max.yield) and increased yield (IY k) after application of $\mathrm{K}$ fertilizer averaged at $10200 \mathrm{~kg} \mathrm{ha}^{-1}$ and $1100 \mathrm{~kg} \mathrm{ha}^{-1}$, respectively. Significant variability was evident in K0 yield and Max.yield over the years. Maize hybrids and different soil types had significant differences in IY yield. Meanwhile, IY can either increase or decrease depending on $\mathrm{K} 0$ yield, which suggest that a suitable $\mathrm{K}$ fertilizer can improve the yield, whereas excessive $\mathrm{K}$ fertilizing would have no obvious effect on the yield. In addition, the yield was found to be affected by environment, 
maize hybrids, soil types, and $\mathrm{K}$ fertilizer rate. Therefore, the research of precision $\mathrm{K}$ fertilizer application on different soils type and different maize hybrids in different climate condition should be carried out in the future, which will be of epoch-making significance for high-yield and high-efficiency of spring maize in Jilin province, in Northeast China.

Acknowledgements. The authors would like to acknowledge the National Key R\&D Program of China (2017YFD0201804, 2018YFD0800101); Natural Science Foundation of Jilin province, China (20170101004JC); and the National Natural Science Foundation of China (Grant No. 31471945) for their financial support.

\section{REFERENCES}

[1] Chen, G., Zhang, Z. D., Wang, P., Tao, H. B. (2012a): Comprehensive analysis on Ear characters and yield of the different maize varieties in dryland area. - Journal Crops 5: 100-104 (in Chinese).

[2] Chen, N. X., Lv, C. H., Liu, Y. M. (2012b): Effect of 3414 formula fertilization on maize yield and nutrient content (in Chinese.). - Journal Barley and Cereal Sciences 4: 26-28.

[3] Darunsontaya, T., Suddhiprakarn, A., Kheoruenromne, I., Prakongkep, N., Gilkes, R. (2012): The forms and availability to plants of soil potassium as related to mineralogy for upland Oxisols and Ultisols from Thailand. - Geoderma 170: 11-24.

[4] Drury, C. F., Tan, C. S. (1995): Long-term (35years) effects of fertilization, rotation and weather on corn yield. - Canadian Plant Science 75: 355-362.

[5] Epstein, E., Bloom, A. J. (2005): Mineral Nutrition of Plants: Principles and Perspectives. $2^{\text {nd }}$ Ed. - Sinauer Associates, Inc., Sunderland, MA.

[6] Gao, Q., Li, C. L., Feng, G. Z., Wang, J. F., Cui, Z. L., Chen, X. P., Zhang, F. S. (2012): Understanding yield response to nitrogen to achieve high yield and high nitrogen use efficiency in rainfed corn. - Agronomy Journal 104: 165-168.

[7] Gong, Z. T., Chen, Z. C., Luo, G. B., Zhang, G. L., Zhao, W. J. (1999): Reference to Chinese soil taxonomy. - Journal Soils 2: 57-63 (in Chinese).

[8] Ladha, J. K., Pathak, H., Krumpnik, T. J., Six, J., Kessel, C. V. (2005): Efficiency of fertilizer nitrogen in cereal production: retrospects and prospects. - Advances in Agronomy 87: 85-156.

[9] Li, H. L., Zhang, W. F., Zhang, F. S., Du, F., Li, L. K. (2010): Chemical fertilizer use and efficiency change of main grain crops in China. - Journal Plant Nutrition and Fertilizer Science 16: 1136-1143 (in Chinese).

[10] Li, Y. Z., Liu, G. L., Zhang, H. Y. (2001): The relationship of light and temperature factor and yield maize. - Journal Acta Agriculture Boreali-Occidentalis Sinica 10: 67-70 (in Chinese).

[11] Liu, Y. J., Wei, B., Hu, E. L., Wu, Y. Q., Huang, Y. B. (2011): Yield stability of maize hybrids evaluated in national maize cultivar regional trials in southwestern China using parametric methods. - Agricultural Sciences in China 10: 1323-1335.

[12] National Bureau of Statistics of China (2007): China Statistical Yearbook. - China Statistics Press, Beijing (in Chinese).

[13] National Bureau of Statistics of China (2011): China Statistical Yearbook. - China Statistics Press, Beijing (in Chinese).

[14] Ogundijo, S., Adetunji, M. T., Azeez, J. O., Arowolo, T. A. (2017): Integrated fertilizer management: influence on soil nitrogen, available phosphorus, potassium, nutrient uptake and maize yield. - Communications in Soil Science and Plant Analysis 48: 943-954. 
[15] Ortas, I. (2018): Influence of potassium and magnesium fertilizer application on the yield and nutrient accumulation of maize genotypes under field conditions. - Journal of Plant Nutrition 41(3): 330-339.

[16] Peng, C., Gao, H. J., Niu, H. H., Yue, Y. L., Zhu, P. (2008): Long-term effects of fertilization and weather on corn yields in a clay loam soil in Northeast China - Journal of Maize Sciences 16: 179-183 (in Chinese).

[17] Ren, H., Li, Y. Y., Han, C. W., Zhou, P. (2010): Potential analysis of maize increasing yield in Jilin Province - Journal Maize Science 18: 148-152 (in Chinese).

[18] Shen, Q. R., Tan, J. F., Qian, X. Q. (2008): The Theory of Soil and Fertilizer Science. 11 st Ed. - Beijing, China (in Chinese).

[19] Sun, S. X. (2010): Popularization and effect of corn hybrid in China. - Journal Crops 3: 121-124 (in Chinese).

[20] Tabu, I. M., Obura, R. M., Bationo, A., Mumera, L. (2006): Effect of soil fertility management and nitrogen fertilizer rate on maize yield in small holder farmers fields. Journal of Agronomy 5: 191-195.

[21] Tenkorang, F., Lowenberg-DeBoer, J. (2009): Forecasting long-term global fertilizer demand. - Nutrition Cycling Agroecosystems 83: 233-247.

[22] Tian, X.; Li, C.; Zhang, M.; Lu, Y.; Guo, Y.; Liu, L. (2017): Effects of controlled-release potassium fertilizer on available potassium, photosynthetic performance, and yield of cotton. - Journal Plant Nutrition Soil Science 180: 505-515.

[23] Tolk, J. A., Howell, T. A., Evett, S. R. (1999): Effect of mulch, irrigation and soil type on water use and yield of maize. - Soil \& Tillage Research 50: 137-147.

[24] Van Reewijk, L. P. (1992): Procedures for Soil Analysis. $3^{\text {rd }}$ Ed. - ISRIC, Wageningen, the Netherlands.

[25] Vasal, S. K. (2000): The quality protein maize story. - Food and Nutrition Bulletin 21. https://doi.org/10.1177/156482650002100420.

[26] Wang, L. (1998): Jilin Soil. - Chinese Agricultural Press, Beijing (in Chinese).

[27] Wang. X. B., Hoogmoed, W. B., Cai, D. X., Perdok, U. D., Oenema, O. (2007): Crop residue, manure and fertilizer in dryland maize under reduced tillage in northern China: II Nutrient balances and soil fertility. - Nutrition Cycling Agroecosytems 79: 17-34.

[28] Wang, X. F., Zhang, K., Wang, L. C., Zhang, G. G., Xie, J. G. (2004): The main factors of effect of Spring maize on increasing yield and use efficiency with potassium fertilizer. - Presiding for the 5th Cross Straits Soil Fertilizer International Conference, pp. 192-198 (in Chinese).

[29] Weber, R., Golebiowska, H. (2010): Discriminatory analysis of the yield variability of maize hybrids depending on the doses and time of herbicide application. - Acta Scientiarum Polonorum Agricultura 9: 69-76.

[30] Xie, J. C. (2000): Potassium in China Agriculture. - Hohai University Press, Nanjing (in Chinese).

[31] Zhang, F. S., Wang, J. Q., Zhang, W. F., Cui, Z. L., Ma, W. Q., Chen, X. P., Jiang, R. F. (2008): Nutrient use efficiencies of major cereal crops in China and measures for improvement. - Journal Acta Pedologica Sinica 45: 915-924 (in Chinese).

[32] Zhang, H. M., Yang, X. Y., He, X. H., Xu, M. G., Huang, S. M., Liu, H., Wang, B. R. (2011): Effect of long-term potassium fertilization on crop yield and potassium efficiency and balance under wheat-maize rotation in China. - Pedosphere 21: 154-163.

[33] Zheng, H. J., Dong, Z. T. (2000): Relationships between ecological factors and maize yield. - Journal of Shandong Agricultural University (Natural Science) 31: 315-319 (in Chinese).

[34] Zoerb, C., Senbayram, M., Peiter, E. (2014): Potassium in agriculture-status and perspectives. - Journal of Plant Physiology 171: 656-669. 